\section{ChemRus 2021}

O ChemRus desafiou os alunos do ensino secundário a realizar um vídeo original de uma reação química com destaque para os Objetivos de Desenvolvimento Sustentável (ODS), estabelecidos pela Organização das Nações Unidas em 2015, e conhecidos como Agenda 2030. Em 2021, apesar de todas as restrições impostas pela pandemia da COVID-19, a 10. a edição do concurso contou com 15 vídeos originais de equipas de escolas de todo o país. É de destacar que este ano os vídeos são marcados pela presença das máscaras em adição ao equipamento de segurança individual em laboratório e por vídeos de Química em casa. 0 nível competitivo dos vídeos apresentados, quer ao nível científico, quer ao nível das artes gráficas, presentearam-nos com uma decisão difícil. Assim, o júri selecionou dois vencedores:

- "De óleo de cozinha a sabão", da equipa constituída por Inês Ferreira, Juliana Meireles e Francisco Pereira e pela professora Clara Tomé da Escola Secundária da Boa Nova - Leça da Palmeira.

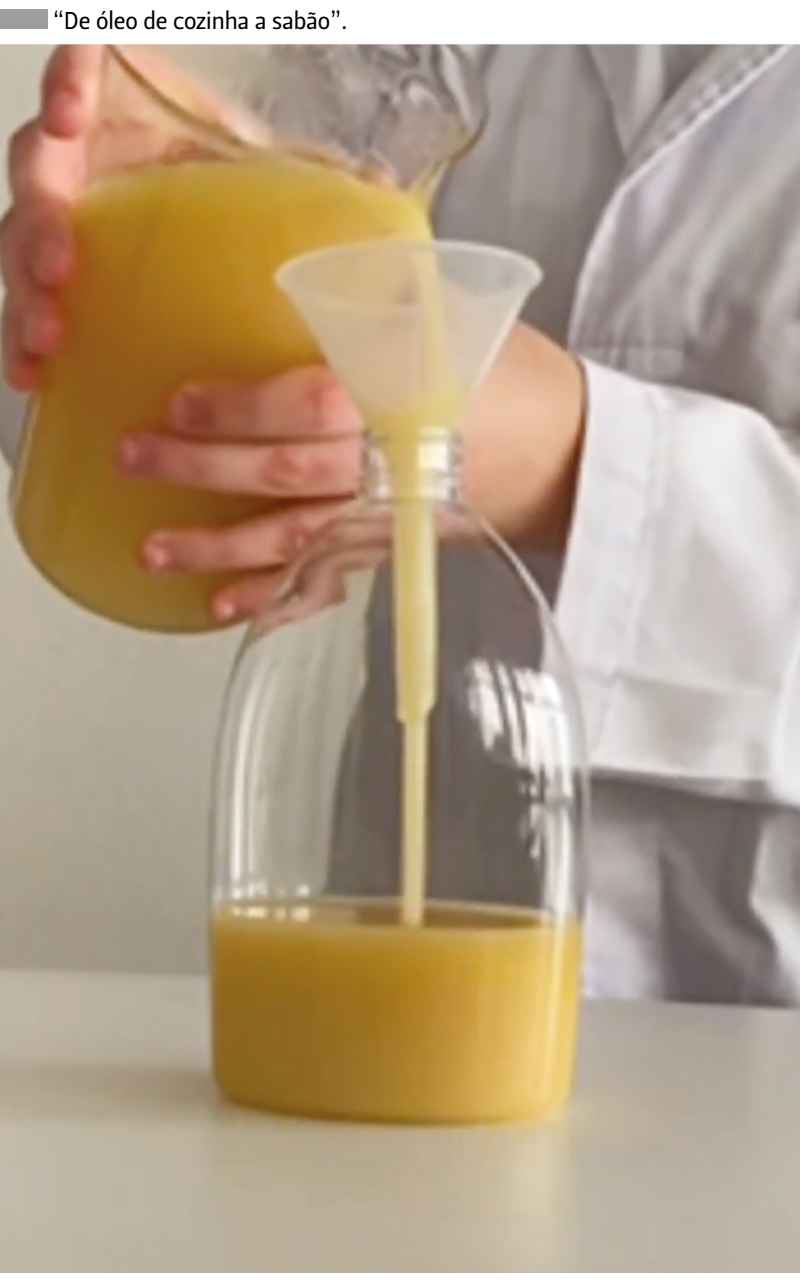

- "Síntese de um polímero biodegradável", da equipa constituída por Ana Moreira e João Magalhães e pela professora Conceição Machado da Escola Secundária de Caldas das Taipas.

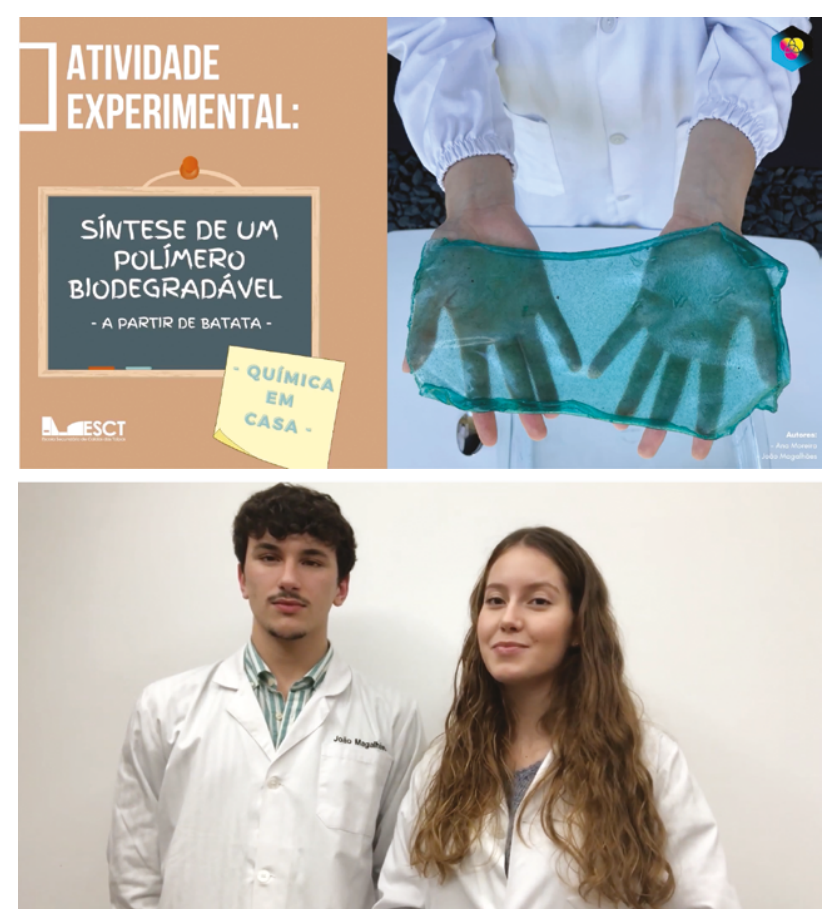

"Síntese de um polímero biodegradável", João Magalhães e Ana Moreira.

Foram também atribuídas Menções Honrosas a:

- "De óleo alimentar a biodiesel", da equipa constituída pela Matilde Tavares, Gustavo Silva e Gonçalo Cunha e pela professora Clara Tomé da Escola Secundária da Boa Nova - Leça da Palmeira.

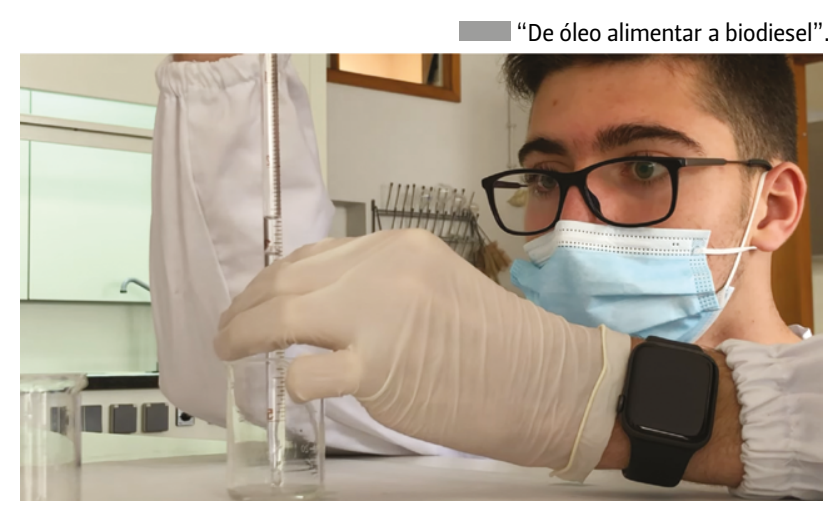

- "Nunca digas: desta água não beberei", da equipa constituída por Beatriz Sá Pinto, Catarina Sá Pinto, João Vicente e pela professora Clara Tomé da Escola Secundária da Boa Nova - Leça da Palmeira. 


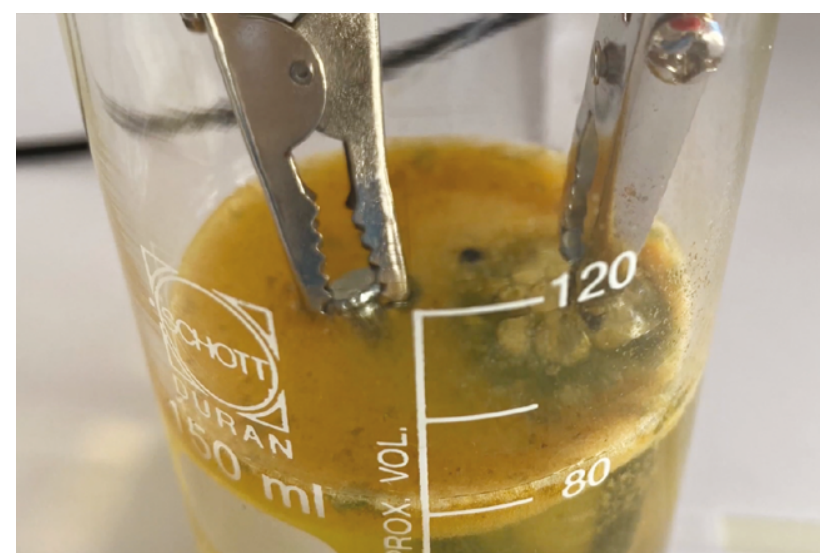

"Nunca digas: desta água não beberei".
Os elementos dos grupos vencedores, bem como o professor responsável, foram agraciados com um prémio de participação, a título pessoal, com o apoio do Centro Ciência Viva de Lisboa e da Gradiva. Visite o canal YouTube do GQJ e conheça todos os participantes.

Agradecemos a todos os participantes e um agradecimento especial aos elementos do júri do concurso, Adriano Cerqueira, Diana Mendes Freire, Irina Pinheiro e Mário Nuno de Matos Sequeira Berberan e Santos.

Carina Crucho

Grupo de Químicos Jovens

gqj@spq.pt

\section{IUPAC Anuncia as Dez Principais Tecnologias Emergentes de 2021 em Química}

\author{
IUPAC Top Ten Emerging \\ Technologies in Chemistry 2021
}

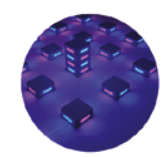

Blockchain

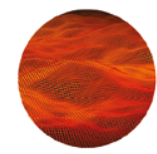
Sonochemica
coating

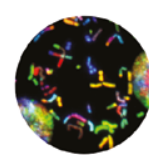

Semisynthetic life

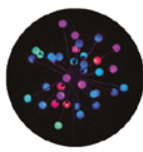

Chemo-

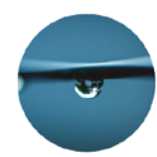

Superwettability

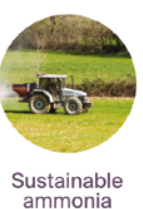

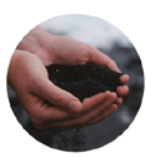

Artificial humus

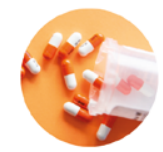

Targeted protein degradation
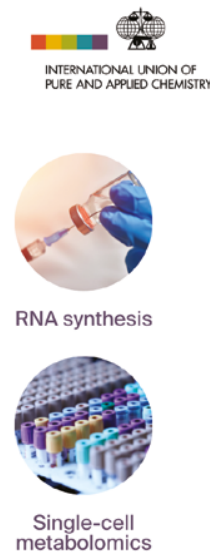

A União Internacional de Química Pura e Aplicada (IUPAC) divulgou os resultados da sua pesquisa de 2021 para as dez principais tecnologias emergentes em Química. 0 objetivo deste projeto é demonstrar o valor da Química e informar o público em geral sobre como as ciências químicas contribuem para o bem-estar da sociedade e para a sustentabilidade do Planeta. Desde 2019 que o júri, constituído por um grupo internacional de especialistas de diferentes áreas, seleciona tecnologias emergentes entre novas descobertas científicas e tecnologias totalmente comercializadas, e aquelas com maior capacidade de abrir novas oportunidades em áreas onde a Química desempenha um papel fundamental. Os selecionados de 2021 são, por ordem alfabética:

- Degradação direcionada de proteínas

(Targeted protein degradation);

- Matéria húmica artificial a partir de biomassa;

- Metabolómica unicelular;

- Produção sustentável de amoníaco;

- Quimioluminescência para uso biológico;

- Revestimentos sonoquímicos;

- Síntese química de ARN e ADN;

- Supermolhabilidade (Superwettability);

- Tecnologia Blockchain;

- Vida semi-sintética.

A próxima edição para eleger as dez principais tecnologias emergentes em química de 2022 já começou. Faça a sua nomeação até 31 de março de 2022 em cognitoforms.com/IUPAC1/TopTenEmergingTechnologiesInChemistry2022. Para obter mais informações, consulte iupac.org/what-we-do/top-ten.

\section{Bruno Machado \\ brunofm@fe.up.pt}

